Eu deveria ainda tratar nesta palestra de leasing internacional, mas tenho certeza de que esse assunto é tão momentoso e está tanto na mente de todos, que outros congressıstas o ventilarão

exaustivamente.

\title{
Indústria nacionalizada de petróleo. Sistemática venezuelana.
}

\author{
Andrés Aguilar Mawdsley, advogado \\ venezuelano, especializado em direito \\ internacional, consultor jurídico da Empresa de \\ Petróleos da Venezuela.
}

Andrés Aguilar Mawdsley
Referir-me-ei às experiências da Empresa de Petróleos da Venezuela e da própria Venezuela sobre a nacionalização da indústria do petróleo, ocorrida em 1975, quando, então, foram reservadas ao Estado todas as atividades de exploração, produção, manufatura ou refino, transporte por vias intereres, comércio interno e externo, com relação aos produtos derivados de hidrocarbonetos.

Essa indústria fundamental da Venezuela está sendo manejada por uma empresa holding denominada Empresa de Petróleos da Venezuela e um conjunto de filiais, a saber: empresas operadoras, que são as que realmente realizam os trabalhos de exploração, produção, refino, etc.; empresas encarregadas da investigação científica e tecnológica em matéria petrolífera; e empresas, cujo objetivo consiste em unificar o processo de aquisição de bens e equipamentos para a indústria. Todas essas empresas estão organizadas em bases comerciais e sob o princípio fundamental do autofinanciamento.

\section{O autofinanciamento da indústria nacionalizada do petróleo}

Por disposição legal, a matriz da empresa de $\mathrm{Pe}$ tróleos da Venezuela recebe $10 \%$ das vendas líquidas da exportação do petróleo, com o fim de criar um fundo que permita financiar as atividades e os projetos necessários para manter e elevar o potencial de produção, modificar os padrões de refino de maneira a melhor responder às exigências do mercado, explorar áreas novas e desenvolver outras áreas conhecidas que tenham petróleos de características especiais ou petróleos pesados, e, por fim, o desenvolvimento de investigações capazes de propiciar produto de qualidade à base desses petróleos pesados. Semelhante programa envolve grandes inversões.
Além dos $10 \%$, base do autofinanciamento, o Estado venezuelano, nos sete anos de operação da empresa estatal, tem-se contentado com os recursos que aufere pela aplicação de leis fiscais, porque a indústria petrolífera está sujeita, como acontecla com relação à indústria privada, aos mesmos impostos: de exploração (regalía) e sobre a renda. Através desses tributos o Estado recebe porção importante das vendas geradas pela indústria, preservando, entretanto, certa margem - de que bem poderia legitimamente apropriar-se como acionista - para investimento e aumento das possibilidades de autofinanciamento.

Formou-se, assim, um montante que já atingiu a grandeza de sete bilhões de dólares, que a indústria petrolífera vem depositando em diferentes bancos de diferentes países, a prazos variados e em diversos tipos de inversões: certificado de depósitos, aquisição de bônus e outros papéis, etc. Vale a pena ressaltar que esses depósitos são feitos não somente em bancos de países desenvolvidos, como os Estados Unidos, Reino Unido, República Federal da Alemanha ou Japão, mas, o são, também, em bancos de países em desenvolvimento. Diga-se de passagem que tais recursos certamente são aplicados pelas instituições depositárias, aumentando-lhes as disponibilidades creditícias. Ese toca aqui em outro ponto, que parece muito importante - cooperação sul-sul.

\section{Cooperação sul-sul}

Acredita a Venezuela - sem prejuízo da máxima utilização das possibilidades oferecidas pelas instituições internacionais de financiamentos intergovernamentais, nacionais ou privadas - que é preciso, também, que os países em desenvolvimento se ajudem reciprocamente e que cada qual, na me- 
dida de suas possibilidades, contribua para a solução dos problemas dos demais. A indústria petrolífera consubstancia expressivo exemplo desse estímulo para o financiamento de uma série de programas de origem interna ou externa.

No que concerne ao financiamento interno, a indústria petrolífera inclui em seus programas de trabalho o fomento das indústrias venezuelanas que produzem bens de capital, o que é particularmente importante para a indústria de aço, a fabricação de tubos, utilizados em grande escala nos trabalhos de prospecção; a produção e transporte de petróleo bruto; a indústria de alumínio - outra grande indústria da Venezuela - , sem falar da indústria petroquímica, também adstrita ao setor petrolífero estatal. De maneira que estimula a produção nacional de bens de capital, assim como os serviços, porque justamente uma das metas a que se propôs a indústria petrolífera foi a utilização, o fomento e o desenvolvimento da capacidade técnica da engenharia nacional e, em geral, de todas as demais áreas técnicas.

Quanto aos programas de financiamento externo, destaca-se o Programa de Cooperação Energética, que a Venezuela, primeiro sozinha, e, a partir de agosto de 1980, juntamente com o México, vem desenvolvendo, a fim de permitir aos países centro-americanos e do Caribe atenderem compromissos oriundos do pagamento das importações de petróleo bruto e de produtos derivados do petróleo. México e Venezuela têm destinado certo volume, cerca de 160.000 barris diários de petróleo, para satisfazer às necessidades daqueles países, vendidos, como usualmente, mediante carta de crédito a prazos variáveis, segundo as circunstâncias, de trinta a sessenta dias, sem caráter de empréstimo ou facilidades qualificáveis de concessões gratuitas. Separase, desse modo, nitidamente, a função comercial, que a Empresa de Petróleos da Venezuela e suas subsidiárias realizam, da função de assistência que o Estado venezuelano presta, através de outros órgãos distintos da empresa petrolífera. A empresa estatal vende a preços notificados, como o faria a qualquer comprador, e é através de outros mecanismos de financiamento que os países da América Central ou do Caribe recebem $30 \%$ do montante da fatura pagável a prazos relativamente cômodos, parece que de cinco anos, a juro de $4 \%$. Há possibilidade de obtenção de prazos maiores com juros menores, se os empréstimos se destinarem a projetos de desenvol- vimento, particularmente em matéria energética. 0 que se objetiva é habilitar esses países a desenvolverem a capacidade de produção para que possam, por si só, atender às suas próprias necessidades energéticas. O programa, iniciado pela Venezuela e continuado juntamente com o México, após a declaração dos presidentes da Venezuela, México e São José da Costa Rica, em 1980, foi prorrogado pelos dois primeiros países em agosto de 1982.

Além dessa cooperação específica a países que, por motivos conhecidos, têm dificuldades para atender aos mencionados pagamentos, a Venezuela, com os recursos petrolíferos e através de diferentes mecanismos, particularmente do fundo criado pela OPEP, tem contribuído com vultosas quantias para o financiamento, não apenas de programas de desenvolvimento na vizinha área dos países centro-americanos e do Caribe, senão também a nivel mundial.

Desejaria, ainda, citar, para concluir, duas outras possibilidades, que poderiam ser muito úteis também ao Brasil, para outros produtos e talvez em outros quadros. Em primeiro lugar, um programa já bastante adiantado - mas sobre o qual não se podem indicar dados específicos porque ainda está em estudos - , é o de estabelecer uma sociedade de economia mista, com participação de capital venezuelano e europeu, para refino, na Europa, de determinados tipos de petróleo bruto. A Europa teria a segurança do emprego do produto, enquanto a Venezuela, a garantia de colocação de determinado volume de sua produção e de colaboração no melhoramento de certos tipos de petróleo cru. A reciprocidade de interesses implicaria em contribuição igualitária, isto é, caberia à Venezuela $50 \%$ do capital. A idéia do projeto é combinar o interesse de um país produtor e exportador, neste caso de petróleo, com o de outro país empenhado em receber esse bem e em transformá-lo aproveitando a facilidade de instalações e a rede de distribuição.

Outro projeto que também ainda está em fase de estudos e sujeito à decisão de diferentes autoridades é o de uma cooperação mais estreita entre as empresas petroliferas estatais mais importantes da América Latina: Petrobrás, Petróleo do México - Pemex e Empresa de Petróleos da Venezuela. Bem se pode imaginar a importância de semelhante cooperação entre aquelas empresas, consideradas as maiores do mundo. 